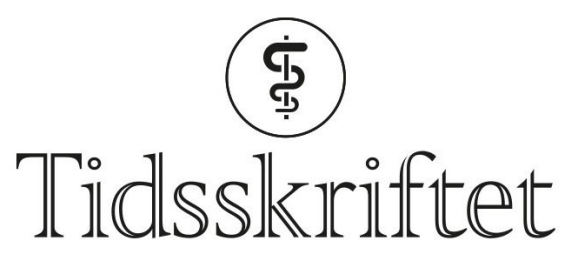

DEN NORSKE LEGEFORENING

\title{
Rettelse: Ser inn i fremtiden
}

RETTELSE

ØYVIND STOPLE SIVERTSEN

Tidsskr Nor Legeforen 2018; 138: 1650-2.

I Tidsskriftet nr. 17/2018 på s. 1652 skal det stå: Ved Sykehuset Innlandet jobbes det med prosjekter innenfor behandling av depresjon hos eldre samt trening på elektrokonvulsiv terapi (ECT) ved bruk av VR-teknologi.

Vi beklager feilen, den er rettet på nett.

Publisert: 16. november 2018. Tidsskr Nor Legeforen. DOI: 10.4045/tidsskr.18.o877

(C) Tidsskrift for Den norske legeforening 2020. Lastet ned fra tidsskriftet.no 